\title{
Front Matter: Volume 8885
}

, "Front Matter: Volume 8885," Proc. SPIE 8885, Laser-Induced Damage in Optical Materials: 2013, 888501 (4 December 2013); doi: 10.1117/12.2051344

SPIE. Event: SPIE Laser Damage, 2013, Boulder, Colorado, United States 


\title{
LASER-INDUCED DAMAGE IN OPTICAL MATERIALS: 2013
}

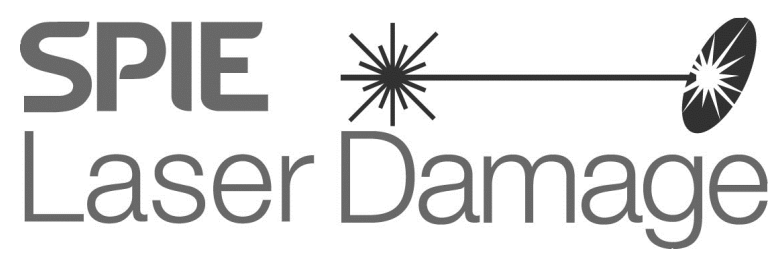

\section{2-25 September 2013 \\ Boulder, Colorado}

\section{Editors}

Gregory J. Exarhos, Vitaly E. Gruzdev, Joseph A. Menapace, Detlev Ristau, MJ Soileau

$$
\begin{aligned}
& \text { Organized by } \\
& \text { SPIE }
\end{aligned}
$$

Cosponsored by

Lawrence Livermore National Laboratory (United States)

Spica Technologies, Inc. (United States)

\section{Cooperating Organizations}

National Institute of Standards and Technology (United States)

CREOL \& FPCE, College of Optics and Photonics, University of Central Florida (United States)

Laser Zentrum Hannover e.V. (Germany)

University of Missouri-Columbia (United States)

Pacific Northwest National Laboratory (United States)

Laboratory for Laser Energetics, University of Rochester (United States)

Office of Naval Research (United States)

$$
\text { Founding Organizers }
$$

Arthur H. Guenther and Alexander J. Glass

\section{Technical Contact}

James Burrus, National Institute of Standards and Technology (United States)

\section{Published by}

SPIE

\section{Proceedings of SPIE Volume 8885}

\author{
Proceedings of SPIE, 0277-786X, v. 8885
}

SPIE is an international society advancing an interdisciplinary approach to the science and application of light.

Laser-Induced Damage in Optical Materials: 2013, edited by Gregory J. Exarhos, Vitaly E. Gruzdev, Joseph A. Menapace, Detlev Ristau, MJ Soileau, Proc. of SPIE Vol. 8885, 888501 - (c) 2013 SPIE · CCC code: 0277-786X/13/\$18 - doi: 10.1117/12.2051344

Proc. of SPIE Vol. $8885888501-1$ 
The papers included in this volume were part of the technical conference cited on the cover and title page. Papers were selected and subject to review by the editors and conference program committee. Some conference presentations may not be available for publication. The papers published in these proceedings reflect the work and thoughts of the authors and are published herein as submitted. The publisher is not responsible for the validity of the information or for any outcomes resulting from reliance thereon.

Please use the following format to cite material from this book:

Author(s), "Title of Paper," in Laser-Induced Damage in Optical Materials: 2013, edited by Gregory J. Exarhos, Vitaly E. Gruzdev, Joseph A. Menapace, Detlev Ristau, MJ Soileau, Proceedings of SPIE Vol. 8885 (SPIE, Bellingham, WA, 2013) Article CID Number.

ISSN: 0277-786X

ISBN: 9780819497536

Published by

SPIE

P.O. Box 10, Bellingham, Washington 98227-0010 USA

Telephone +1 3606763290 (Pacific Time) F Fax +1 3606471445

SPIE.org

Copyright (C) 2013, Society of Photo-Optical Instrumentation Engineers.

Copying of material in this book for internal or personal use, or for the internal or personal use of specific clients, beyond the fair use provisions granted by the U.S. Copyright Law is authorized by SPIE subject to payment of copying fees. The Transactional Reporting Service base fee for this volume is $\$ 18.00$ per article (or portion thereof), which should be paid directly to the Copyright Clearance Center (CCC), 222 Rosewood Drive, Danvers, MA 01923. Payment may also be made electronically through CCC Online at copyright.com. Other copying for republication, resale, advertising or promotion, or any form of systematic or multiple reproduction of any material in this book is prohibited except with permission in writing from the publisher. The CCC fee code is $0277-786 \mathrm{X} / 13 / \$ 18.00$.

Printed in the United States of America.

Publication of record for individual papers is online in the SPIE Digital Library.

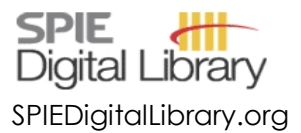

Paper Numbering: Proceedings of SPIE follow an e-First publication model, with papers published first online and then in print and on CD-ROM. Papers are published as they are submitted and meet publication criteria. A unique, consistent, permanent citation identifier (CID) number is assigned to each article at the time of the first publication. Utilization of CIDs allows articles to be fully citable as soon as they are published online, and connects the same identifier to all online, print, and electronic versions of the publication. SPIE uses a six-digit CID article numbering system in which:

- The first four digits correspond to the SPIE volume number.

- The last two digits indicate publication order within the volume using a Base 36 numbering system employing both numerals and letters. These two-number sets start with 00, 01, 02, 03, 04, 05, 06, 07, 08, 09, 0A, 0B ... 0Z, followed by 10-1Z, 20-2Z, etc.

The CID Number appears on each page of the manuscript. The complete citation is used on the first page, and an abbreviated version on subsequent pages. Numbers in the index correspond to the last two digits of the six-digit CID Number. 


\section{Contents}

ix International Program Committee

xi Symposium Welcome

V. E. Gruzdev

xiii Summary of Meeting

D. Ristau

xxv Summary of Roundtable Discussion

V. E. Guzdev

THIN FILMS I

888502 Defect insensitive $100 \mathrm{~J} / \mathrm{cm}^{2}$ multilayer mirror coating process [8885-1]

C. J. Stolz, J. E. Wolfe, P. B. Mirkarimi, J. A. Folta, J. J. Adams, M. G. Menor, N. E. Teslich, R. Soufli, Lawrence Livermore National Lab. (United States); C. S. Menoni, D. Patel, Colorado State Univ. (United States)

THIN FILMS II

888504 Near-ultraviolet absorption-annealing effects in $\mathrm{HfO}_{2}$ thin films subjected to continuous-wave laser irradiation at $355 \mathrm{~nm}$ [8885-3]

S. Papernov, A. A. Kozlov, J. B. Oliver, T. J. Kessler, Univ. of Rochester (United States); B. Marozas, Cornell Univ. (United States)

888506 Investigation of non-quarter wave design on multilayer optical thin film coatings from a heat transfer point of view [8885-5]

M. Ocak, ASELSAN Inc. (Turkey) and Middle East Technical Univ. (Turkey); C. Sert, T. Ö. Okutucu, Middle East Technical Univ. (Turkey)

\section{THIN FILMS III}

888508 Study on the laser-induced damage performance of $\mathbf{H f O}_{2}, \mathbf{S c}_{2} \mathbf{O}_{3}, \mathbf{Y}_{2} \mathbf{O}_{3}, \mathbf{A l}_{2} \mathbf{O}_{3}$ and $\mathrm{SiO}_{2}$ monolayer coatings [8885-8]

M. Zhu, K. Yi, D. Li, H. Qi, Y. Zhao, Shanghai Institute of Optics and Fine Mechanics (China); J. Liu, Shanghai Institute of Optics and Fine Mechanics (China) and Univ. of Chinese Academy of Sciences (China); X. Liu, G. Hu, J. Shao, Shanghai Institute of Optics and Fine Mechanics (China)

888509 Brewster angle thin film polarizing beamsplitter laser damage competition: "S" polarization [8885-9] C. J. Stolz, Lawrence Livermore National Lab. (United States); J. Runkel, Quantel USA (United States)

$88850 A \quad$ Predictive growth model of LID: light intensification model [8885-7]

C. Tan, Multimedia Univ. (Malaysia); D. Patel, Colorado State Univ. (United States); X. Wang, Monash Univ. (Malaysia); D. Schlitz, Colorado State Univ. (United States); P. K. Dehkordi, Monash Univ. (Malaysia);

C. S. Menoni, E. K. P. Chong, Colorado State Univ. (United States) 
8885 0D From ground to space: how to increase the confidence level in your flight optics [8885-12]

W. Riede, P. Allenspacher, M. Lammers, Deutsches Zentrum für Luft- und Raumfahrt e.V. (Germany);

D. Wernham, A. Ciapponi, C. Heese, European Space Research and Technology Ctr. (Netherlands); L. Jensen,

H. Maedebach, S. Schrameyer, D. Ristau, Laser Zentrum Hannover e.V. (Germany)

\section{MATERIALS AND MEASUREMENTS II}

8885 0F Round-Robin experiment on LIDT measurements at $1064 \mathrm{~nm}$ in vacuum for space qualification of optics [8885-14]

S. Schrameyer, H. Mädebach, L. Jensen, D. Ristau, Laser Zentrum Hannover e.V. (Germany); C. Heese, J. Piris,

A. Ciapponi, B. Sarti, European Space Research and Technology Ctr. (Netherlands); P. Allenspacher,

M. Lammers, W. Riede, Deutsches Zentrum für Luft- und Raumfahrt e.V. (Germany); A. Melninkaitis,

G. Batavičiūtè, L. Smalakys, V. Sirutkaitis, Vilnius Univ. (Lithuania)

$88850 \mathrm{H} \quad$ Method for studying laser-induced damage from sparse defects [8885-16]

S. Richman, A. R. Martin, Q. Turchette, T. Turner, Research Electro-Optics, Inc. (United States)

\section{MATERIALS AND MEASUREMENTS III}

8885 0J Contamination resistant antireflection nano-textures in fused silica for laser optics [8885-87]

D. S. Hobbs, B. D. MacLeod, E. Sabatino III, TelAztec LLC (United States); J. A. Britten, C. J. Stolz, Lawrence Livermore National Lab. (United States)

8885 0K High-power laser testing of 3D meta-optics [8885-19]

A. Pung, I. Raghu Srimathi, Y. Li, E. Johnson, Clemson Univ. (United States); M. D. Shinn, Thomas Jefferson National Accelerator Facility (United States); K. J. Lee, R. Magnusson, The Univ. of Texas at Arlington (United States); J. Talghader, L. Taylor, Univ. of Minnesota, Twin Cities (United States); L. Shah, M. Richardson, CREOL, The College of Optics and Photonics, Univ. of Central Florida (United States)

$88850 \mathrm{M}$ Compositional dependent response of silica-based glasses to femtosecond laser pulse irradiation [8885-21]

T. Seuthe, Fraunhofer-Institut für Keramische Technologien und Systeme (Germany); M. Grehn, Technische Univ. Berlin (Germany); A. Mermillod-Blondin, Max-Born-Institut für Nichtlineare Optik und

Kurzzeitspektroskopie (Germany); J. Bonse, Bundesanstalt für Materialforschung und -prüfung (Germany); M. Eberstein, Fraunhofer-Institut für Keramische Technologien und Systeme (Germany)

\section{MATERIALS AND MEASUREMENTS IV}

$88850 \mathrm{~N} \quad$ A unified optical damage criterion based on the probability density distribution of detector signals [8885-22]

T. Somoskoi, C. Vass, Univ. of Szeged (Hungary); M. Mero, Univ. of Szeged (Hungary) and Max Born Institute (Germany); R. Mingesz, Z. Bozoki, Univ. of Szeged (Hungary); K. Osvay, Univ. of Szeged (Hungary) and ELIHu Nkft (Hungary)

$88850 \mathrm{O} \quad$ Laser damage threshold measurements via maximum likelihood estimation [8885-58] J. W. Arenberg, Northrop Grumman Aerospace Systems (United States); M. D. Thomas, Spica Technologies, Inc. (United States) 
$88850 \mathrm{P} \quad$ Examination of multi-shot laser induced damage on uncoated fused silica substrates at the surface and in the bulk material using P-polarized $1 \mathrm{~ns} 1.5 \mathrm{kHz}$ laser pulses at $1064 \mathrm{~nm}$ [8885-24]

F. L. Chiragh, O. A. Konoplev, A. A. Vasilyev, Sigma Space Corp. (United States); D. Poulios, American Univ. (United States); M. A. Stephen, M. A. Krainak, NASA Goddard Space Flight Ctr. (United States)

\section{SURFACES, MIRRORS, AND CONTAMINATION I}

8885 0Q A survey of laser plasma target emissions and contamination effects (Plenary Paper) [8885-25] J. E. Andrew, AWE plc (United Kingdom)

8885 0R Laser-induced contamination and its impact on laser damage threshold [8885-26]

H. Schröder, P. Wagner, Deutsches Zentrum für Luft- und Raumfahrt e.V. (Germany); D. Kokkinos, Univ. de Liège (Belgium); W. Riede, Deutsches Zentrum für Luft- und Raumfahrt e.V. (Germany); A. Tighe, European Space Research and Technology Ctr. (Netherlands)

$88850 \mathrm{~T} \quad$ Phase modulation in high power optical systems caused by pulsed laser-driven particle ablation events [8885-28]

M. J. Matthews, N. Shen, A. M. Rubenchik, J. Honig, J. D. Bude, Lawrence Livermore National Lab. (United States)

\section{SURFACES, MIRRORS, AND CONTAMINATION II}

8885 0W Comparison of material response in fused silica and KDP following exit surface laser- induced breakdown [8885-31]

S. G. Demos, R. A. Negres, R. N. Raman, A. M. Rubenchik, M. D. Feit, Lawrence Livermore National Lab. (United States)

$88850 Z$ Mitigation of laser damage on National Ignition Facility optics in volume production [8885-34]

J. Folta, M. Nostrand, J. Honig, N. Wong, F. Ravizza, P. Geraghty, M. Taranowski, G. Johnson, G. Larkin,

D. Ravizza, J. Peterson, B. Welday, P. Wegner, Lawrence Livermore National Lab. (United States)

\section{MINI SYMPOSIUM: TO HIGH POWER LIMITS OF FIBER LASERS}

888514 Investigation of single-mode fiber output damage by 405nm CW laser light [8885-39]

C. P. Gonschior, E. Landrock-Bill, K.-F. Klein, Technische Hochschule Mittelhessen (Germany); T. Sun, K. T. V. Grattan, City Univ. London (United Kingdom)

888515 Theory of phase-locking of multi-stable fiber amplifier arrays [8885-40]

E. J. Bochove, Air Force Research Lab. (United States); M. R. Zunoubi, State Univ. of New York at New Paltz

(United States); C. J. Corcoran, Corcoran Engineering, Inc. (United States)

\section{FUNDAMENTAL MECHANISMS I}

888516 Laser damage in dielectric films: What we know and what we don't (Plenary Paper) [8885-41] W. Rudolph, L. Emmert, Z. Sun, Univ. of New Mexico (United States); D. Patel, C. Menoni, Colorado State Univ. (United States)

888517 General model for nanosecond-laser induced damage in $\mathrm{KTiOPO}_{4}$ crystals [8885-42]

F. Wagner, Aix-Marseille Univ., CNRS, Institut Fresnel (France); G. Duchateau, Univ. de Bordeaux, CNRS, CEA (France); J.-Y. Natoli, M. Commandre, Aix-Marseille Univ., CNRS, Institut Fresnel (France) 
888518 Understanding the physical and material dynamics of multipulse femtosecond laser interactions with surfaces [8885-43]

T. P. Anderson, C. Zuhlke, C. Wilson, C. Kruse, N. Ianno, S. Ndao, G. Gogos, D. Alexander, Univ. of NebraskaLincoln (United States)

\section{FUNDAMENTAL MECHANISMS II}

8885 1A Application of time-resolved digital holographic microscopy to study femtosecond damage process in thin films [8885-45]

N. Šiaulys, Vilnius Univ. (Lithuania); L. Gallais, Institut Fresnel, CNRS, Aix-Marseille Univ. (France);

A. Melninkaitis, Vilnius Univ. (Lithuania)

8885 1D Interaction of laser pulse with confined plasma during exit surface nanosecond laser damage [8885-48]

A. M. Rubenchik, M. D. Feit, S. G. Demos, Lawrence Livermore National Lab. (United States)

POSTER SESSION: MATERIALS AND MEASUREMENTS

$88851 \mathrm{G}$ Commissioning and first results of the ELI-beamlines LIDT test station [8885-50]

D. Kramer, R. Barros, T. Medřik, J. Hřebíček, D. Peceli, M. Durák, M. Kozlova, B. Rus, Institute of Physics of the ASCR, v.v.i. (Czech Republic)

$88851 \mathrm{H} \quad$ New tools for the dynamical description of laser arrays and other complex systems [8885-53] E. J. Bochove, Air Force Research Lab. (United States); N. Nair, Univ. of Tennessee (United States) and Oak Ridge National Lab. (United States); A. B. Aceves, Southern Methodist Univ. (United States); M. R. Zunoubi, State Univ. of New York at New Paltz (United States)

8885 1J Algorithm for cumulative damage probability calculations in S-on-1 laser damage testing [8885-56] S. Schrameyer, Laser Zentrum Hannover e.V. (Germany) and Cutting Edge Coatings GmbH (Germany); M. Jupé, L. Jensen, D. Ristau, Laser Zentrum Hannover e.V. (Germany)

$88851 \mathrm{~L} \quad$ Laser calorimetric absorptance testing of samples with varying geometry [8885-61] I. Balasa, L. Jensen, D. Ristau, Laser Zentrum Hannover e.V. (Germany)

$88851 \mathrm{M} \quad$ Effect of longitudinal laser mode beating in damage probability measurements [8885-62] G. Batavičiūté, E. Pupka, V. Pyragaité, L. Smalakys, A. Melninkaitis, Vilnius Univ. (Lithuania)

$888510 \quad$ Accelerated life time testing of fused silica for DUV laser applications revised [8885-64] C. Mühlig, S. Bublitz, Institut für Photonische Technologien e.V. (Germany)

$88851 \mathrm{P}$ An empirical investigation of the laser survivability curve: IV [8885-65] J. Arenberg, Northrop Grumman Aerospace Systems (United States); W. Riede, Deutsches Zentrum für Luftund Raumfahrt e.V. (Germany); A. Ciapponi, European Space Research and Technology Ctr. (Netherlands); P. Allenspacher, Deutsches Zentrum für Luft- und Raumfahrt e.V. (Germany); J. Herringer, Arrow Thin Films, Inc. (United States); D. Wernham, European Space Research and Technology Ctr. (Netherlands)

8885 1Q Laser-induced damage density of thick optical components [8885-66] L. Lamaignère, T. Donval, R. Diaz, R. Courchinoux, Commissariat à l'Énergie Atomique (France)

8885 1R Photothermal absorption measurements for improved thermal stability of high-power laser optics [8885-67]

M. Stubenvoll, B. Schäfer, K. Mann, Laser-Lab. Göttingen e.V. (Germany); A. Walter, L. Zittel, Sill Optics GmbH \& Co. KG (Germany) 
$88851 \mathrm{~S} \quad$ How the laser-induced ionization of transparent solids can be suppressed [8885-51]

V. Gruzdev, Univ. of Missouri-Columbia (United States)

$88851 \mathrm{~T} \quad$ A theoretical analysis for temperature dependences of laser-induced damage threshold [8885-52] K. Mikami, Osaka Univ. (Japan); S. Motokoshi, T. Somekawa, Institute for Laser Technology (Japan); T. Jitsuno, Osaka Univ. (Japan); M. Fujita, Institute for Laser Technology (Japan); K. A. Tanaka, Osaka Univ. (Japan)

$88851 \mathrm{U}$ Modeling femtosecond pulse laser damage on conductors using Particle-In-Cell simulations [8885-54] R. A. Mitchell, D. Schumacher, E. Chowdhury, The Ohio State Univ. (United States)

\section{POSTER SESSION: THIN FILMS}

$88851 \mathrm{X} \quad$ Laser damage comparisons of broad-bandwidth, high-reflection optical coatings containing $\mathrm{TiO}_{2}$, $\mathrm{Nb}_{2} \mathrm{O}_{5}$, or $\mathrm{Ta}_{2} \mathrm{O}_{5}$ high index layers [8885-68]

E. S. Field, J. C. Bellum, D. E. Kletecka, Sandia National Labs. (United States)

$88851 \mathrm{Y}$ Confocal photothermal microscopy of thin films based on etalon and thermal lensing effects [8885-72] Z. Sun, A. Mansoori, X. Zhang, L. A. Emmert, Univ. of New Mexico (United States); D. Patel, C. S. Menoni, Colorado State Univ. (United States); W. Rudolph, Univ. of New Mexico (United States)

$88851 \mathrm{Z}$ Development of high resistant anti-reflection coating by using $\mathbf{A l}_{2} \mathbf{O}_{3} / \mathrm{SiO}_{2}$ multilayer [8885-76] Y. Ochi, K. Nagashima, H. Okada, M. Tanaka, Japan Atomic Energy Agency (Japan); R. Tateno, Y. Furukawa, Shimadzu Corp. (Japan); A. Sugiyama, Japan Atomic Energy Agency (Japan)

888520 A comparison of laser-induced-damage-threshold of two types of dielectric polarizing beam splitters [8885-78]

V. Škoda, Crytur spol. s r.o. (Czech Republic)

888521 Characterization and application of $\mathrm{HfO}_{2}-\mathrm{SiO}_{2}$ mixtures produced by ion-beam sputtering technology [8885-80]

S. Kičas, Ctr. for Physical Sciences and Technology (Lithuania); G. Batavičiūté, Vilnius Univ. (Lithuania); K. Juškevičius, T. Tolenis, R. Drazdys, R. Buzelis, Ctr. for Physical Sciences and Technology (Lithuania); A. Melninkaitis, Vilnius Univ. (Lithuania)

888522 Improvements in the laser damage behavior of $\mathrm{Ta}_{2} \mathbf{O}_{5} / \mathrm{SiO}_{2}$ interference coatings by modification of the top layer design [8885-82]

D. Patel, D. Schiltz, P. F. Langton, Colorado State Univ. (United States); L. Emmert, Univ. of New Mexico (United States); L. N. Acquaroli, C. Baumgarten, B. Reagan, J. J. Rocca, Colorado State Univ. (United States); W. Rudolph, Univ. of New Mexico (United States); A. Markosyan, R. R. Route, M. Fejer, Stanford Univ. (United States); C. S. Menoni, Colorado State Univ. (United States)

888523 Performance of multilayer optical coatings under long-term 532nm laser exposure [8885-84] D. Poulios, American Univ. (United States); O. Konoplev, F. Chiragh, A. Vasilyev, Sigma Space Corp. (United States); M. Stephen, NASA Goddard Space Flight Ctr. (United States); K. Strickler, Orbital Sciences Corp. (United States)

888524 Laser-induced damage resistance of 266nm AR coatings [8885-85]

B. Cho, A. Lyu, M. Feldman, Newport Corp. (United States) 
POSTER SESSION: SURFACES, MIRRORS, AND CONTAMINATION

888526 Localized planarization of optical damage using laser-based chemical vapor deposition [8885-69] M. J. Matthews, S. Elhadj, G. M. Guss, A. Sridharan, N. D. Nielsen, Lawrence Livermore National Lab. (United States); J. H. Yoo, D. Lee, C. Grigoropoulos, Univ. of California, Berkeley (United States)

888529 Investigation of subsurface damage impact on resistance of laser radiation of fused silica substrates [8885-75]

K. Juškevičius, R. Buzelis, S. Kičas, T. Tolenis, R. Drazdys, Ctr. for Physical Sciences and Technology (Lithuania); G. Batavičiūtė, E. Pupka, L. Smalakys, A. Melninkaitis, Vilnius Univ. (Lithuania)

8885 2D MRF, ELSM and STED: tools to study defects in fused silica optics [8885-83]

R. Catrin, D. Taroux, P. Cormont, C. Maunier, J. Neauport, Commissariat à l'Énergie Atomique (France)

8885 2E Optical contamination control in the Advanced LIGO ultra-high vacuum system [8885-88]

M. H. Phelps, K. E. Gushwa, California Institute of Technology (United States); C. I. Torrie, California Institute of Technology (United States) and Univ. of Glasgow (United Kingdom)

Author Index 


\section{The International Program Committee of the Laser Damage Symposium XLV: Annual Symposium in Optical Materials}

The International Program Committee of the Laser Damage Symposium is an essential part of the conference gathering representatives from many countries active in the field of high power laser components. Presently, the International Program Committee hosts renowned scientists from the United Kingdom, France, China, Japan, Germany and the United States. Besides providing contributions to the conference programme, the International Program Committee is also active in promoting the conference and in attracting researchers from around the world. The members of the International Programme Committee perform a vital service as an outreach for the conference on the global scale. Individuals with suggestions for the meetings are requested to contact any Committee member who is either in acquaintance or in close proximity. The engagement of the International Program Committee, which initiated participation from around 40 countries during the last several years, is acknowledged here as a major contribution to the success of the conference.

Members of the International Program Committee of the XLV Laser Damage Symposium 2013

James E. Andrew, AWE plc (United Kingdom)

Jonathan W. Arenberg, Northrop Grumman Aerospace Systems (United States)

Mireille Commandré, Institut Fresnel (France)

Stavros G. Demos, Lawrence Livermore National Laboratory (United States)

Leonid B. Glebov, CREOL, The College of Optics and Photonics, University of Central Florida (United States)

Takahisa Jitsuno, Osaka University (Japan)

Klaus Mann, Laser-Laboratorium Göttingen e.V. (Germany)

Carmen S. Menoni, Colorado State University (United States)

Masataka Murahara, Tokai University (Japan)

Jérôme Néauport, Commissariat à l'Énergie Atomique (France)

Semyon Papernov, University of Rochester (United States)

Amy L. Rigatti, University of Rochester (United States)

Wolfgang Rudolph, The University of New Mexico (United States)

Jianda Shao, Shanghai Institute of Optics and Fine Mechanics (China)

Michelle D. Shinn, Thomas Jefferson National Accelerator Facility (United States)

Christopher J. Stolz, Lawrence Livermore National Laboratory (United States)

Detlev Ristau Committee Chair, Laser Zentrum Hannover e.V. (Germany) 
Proc. of SPIE Vol. $8885888501-10$

Downloaded From: https://www.spiedigitallibrary.org/conference-proceedings-of-spie on 26 Apr 2023 Terms of Use: https://www.spiedigitallibrary.org/terms-of-use 


\title{
Symposium Welcome
}

\section{On the occasion of the SPIE Laser Damage Symposium - Forty Fifth Annual Symposium on Optical Materials for High Power Lasers}

\author{
Vitaly E. Gruzdev \\ University of Missouri (USA)
}

On behalf of co-chairs of this meeting, Gregory Exarhos, Joseph Menapace, Detlev Ristau, M. J. Soileau, and me, I extend a hearty welcome to all participants of SPIE Laser Damage Symposium - the Forty Fifth Annual Symposium on Optical Materials for High-Power Lasers held at the NIST facility in Boulder, Colorado. Since the first meeting organized by two co-founders - Art Guenther and Alex Glass - in 1969, the symposium has been performing the role of major international platform for lively discussions and communications between researchers and engineers from academics, industry and military related to all aspects of laser-induced damage. Fluctuating from year to year, the number of presentations has the strong trend to increase indicating the enormous vitality of this field and the continuously growing interest to the related topics. Among motivations of doing research in this field are continuous extension of the domain of available laser parameters towards shorter pulses, shorter wavelengths, and higher powers; development of novel lasers; and operation of the traditional lasers in new environments and conditions. The amazing progress towards ultrashort laser pulses provides novel capabilities for better understanding of the fundamental mechanisms of lasermaterial interactions that initiate laser damage in optical materials. Also, modern ultrafast laser systems have enabled development of multiple novel techniques and methods for characterization of optical properties of various materials that are employed in high-power lasers. Rapid progress in various fields of material science has resulted in novel optical materials (e.g., nanostructured surfaces and components for 3D meta-optics) with high potential of applications in highpower laser systems. All those developments continuously support interest to the field of laser damage that is very likely to stay popular even in the following decades.

In view of those developments, it is important to track the previous research. Proceedings of the Boulder Damage Symposium (BDS) have become the most complete and major resource of information on laser damage and multiple related areas compiled from the early stages of that field onwards. The 40-year collection of the Proceedings (from 1969 to 2008 inclusive) has been published in a single DVD distributed among participants of this symposium from 2009. The tremendous efforts of the authors to prepare the manuscripts for this series of Proceedings of SPIE help to maintain the unique status of the Proceedings and are gratefully acknowledged here. In addition to the Proceedings, Special Section on Laser Damage was published in Optical Engineering - the major journal of SPIE - in December 2012. It compiled 18 papers on different aspects of laser damage most of which were presented at this Symposium. The Special Section has attracted significant attention of readers and has received very good feedback from the contributed authors. Those facts have motivated the organizers to prepare and publish another Special Section on Laser Damage in Optical Engineering in 2014.

Significant contribution to the success of the BDS has been done by the International Program Committee (IPC) representing leading research centres and groups of the laser-damage community worldwide. Presently, the Committee consists of representatives from the UK, Germany, France, Japan, China and the United States of America. Besides providing contributions to the conference programme, the International Program Committee is also active in promoting the conference and in attracting researchers from around the world. The engagement of the Committee that initiated participation from more than 30 countries from America, Europe, Asia, Africa and Australia during the last decade is acknowledged here as being very important. Tremendous efforts of the IPC Chair - Dr. Detlev Ristau of Laser Zentrum Hannover (Germany) - to keep IPC actively working are acknowledged.

Following the 45-year tradition, the conference addresses four core topics including Materials and Measurements, Fundamental Mechanisms, Thin Films as well as Surfaces, Mirrors and Contamination. One invited presentation is delivered for each of the topics to provide overview of particular research directions and educate the younger generation of the conference participants. In order to track the current rends in research and further intensify the scientific dialogue at this meeting, a mini-symposium dedicated to a hot current topic in laser material interaction is organised every year since 1992. This year mini-symposium on "High Power Limits of Fiber Lasers" is chaired by Dr. Leonid Glebov from 
the University of Central Florida. It has attracted a number of interesting contributions from industrial companies and research institutes.

Continuing the success of the damage competition held first time in 2008, Chris Stolz has kindly organized another competition with the target to review the present state of the art in multilayer coatings for Brewster-angle polarizing beamsplitters. This initiative has found a broad resonance within the community and resulted in samples submitted by companies and research institutes from China, Japan, Germany, and the United States of America. Sample testing was performed by Spica Technologies, Inc. (USA) accomplished an enormous amount of work by evaluating nanosecond laser-induced damage threshold of all the samples. This outstanding effort is appreciated by the community, and the organizers acknowledge this special contribution by Chris Stolz. Chris Stolz delivered a talk about the competition at the mini-symposium and has prepared a summary paper on the competition which can be found in the present volume of the conference proceedings.

One of the young traditions of the symposium is to acknowledge authors who presented notable results at the previous year's meeting. The authors receive Best Presentation awards consisting of a cut-glass piece of art with symposium emblem and date and names of the authors embedded into the glass by controlled laser-induced damage made with focused beam from a Q-switched laser. Bearing in mind the experience of the previous years, a solid rule has been introduced: for the authors nominated to receive this award, it is mandatory to prepare and publish manuscripts of their presentations in the conference proceedings.

Much of the success of the meeting can be attributed to the untiring efforts of the SPIE staff: Pat Wight (this year Conference Program Coordinator), Diane Cline (Symposium Secretary), and Joel Shields (Proceedings Coordinator) as well as Carly Limtiaco from Lawrence Livermore National Lab (Symposium Assistant). The organizers also acknowledge the support of the NIST staff and especially Kent Rochford and James Burrus (NIST) for coordinating activities and arranging for the audio-video facilities in the meeting room. We gratefully appreciate the annual co-sponsoring from the Lawrence Livermore Laboratory significantly supported this meeting. The contribution of Spica Technologies, Inc. (USA) performed the laser damage tests on optical coatings for the annual laser-damage thin-film competition is greatly appreciated. We appreciate support from Pacific Northwest National Laboratory and Office of Naval Research. We also acknowledge the other cooperating organizations: School of Optics - CREOL and FPCE, College of Optics and Photonics, University of Central Florida; and University of Missouri.

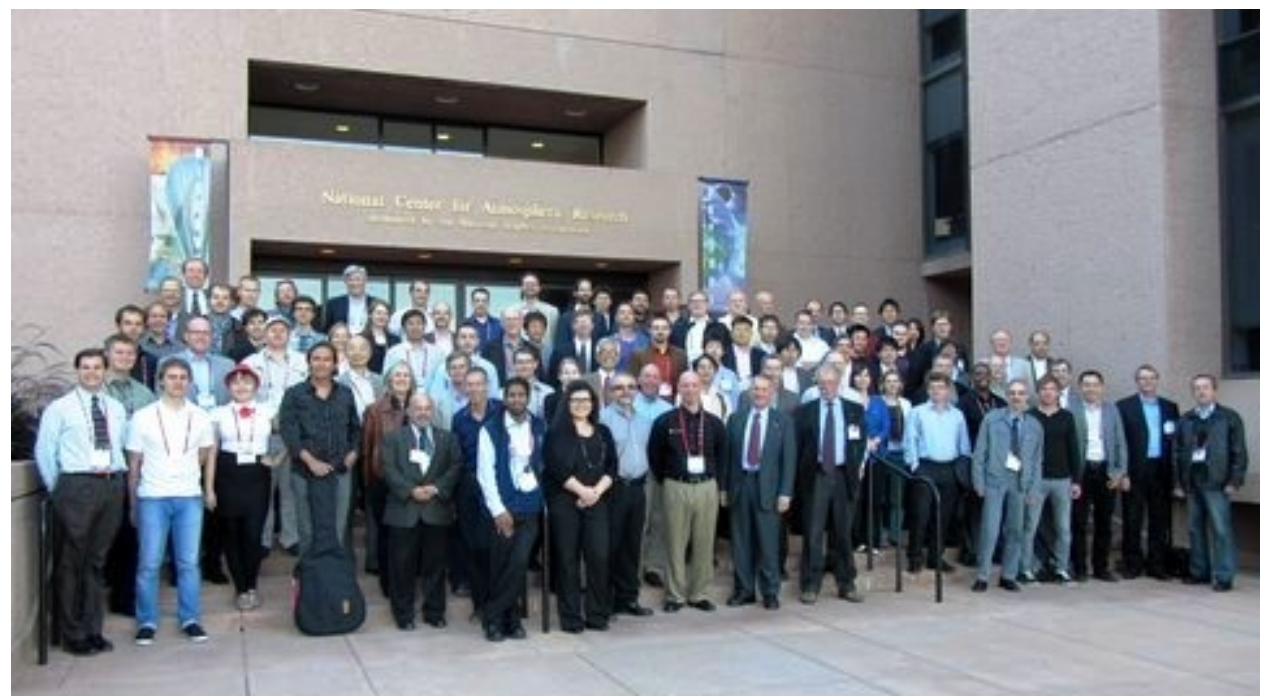

Participants of the $45^{\text {th }}$ Annual Laser Damage Symposium at the entrance to the National Institute of Atmospheric Research in Boulder, CO. 


\title{
Summary of Meeting
}

\author{
SPIE Laser Damage \\ $45^{\text {th }}$ Annual Symposium \\ on Optical Materials for High-Power Lasers \\ 22-25 September 2013
}

\author{
Detlev Ristau \\ Department of Lasercomponents \\ Laser Zentrum Hannover e.V. \\ Hannover, Germany
}

\begin{abstract}
The 45 ${ }^{\text {th }}$ Annual Symposium on Optical Materials for High-Power Lasers (2013 Laser Damage) is one of the major forums for the presentation of scientific research results in the field of laser damage. Founded more than 4 decades ago in 1969, the conference features the four topics of main relevance in the field: thin films; surfaces, mirrors and contamination; fundamental mechanisms; materials and measurements. In the present summary, besides some factual information on the conference, a brief review on the presented scientific achievements will be given.
\end{abstract}

Key words: laser damage, laser interaction, optical components, optical fabrication, optical materials and properties, thin film coatings, contamination.

\section{Introduction}

The SPIE Laser Damage-45th Annual Symposium on Optical Materials for High-Power Lasers (a.k.a. the Boulder Damage Symposium, because of its Boulder, Colorado venue) was held again concurring with the long tradition of this conference series. The present proceedings summarize the papers contributed as oral and poster presentations to the 45th Annual Symposium on Optical Materials for High-Power Lasers. As all previous events of the series, this conference was held at the National Institute of Standards and Technology facility in Boulder, Colorado during the time period 22-25 September 2013. The day before the session started, on Sunday evening, a round table discussion was held dedicated to effects of laser field enhancement in laser-induced damage. The vivid discussion on this current topic was stimulated by the two initiators of the round table, MJ Soileau (University of Central Florida, United States) and Vitaly Gruzdev (Department of Mechanical and Aerospace Engineering, University of Missouri, United States). The attendees of the conference were welcomed by Vitaly Gruzdev who also congratulated the 2012 best poster and oral presentation award winners. This ceremony was assisted by Joseph A. Menapace (Lawrence Livermore National Lab., United States) handing over the glass plaques specially designed for the award winners. Again, the symposium was structured in four separate sessions dedicated to the major interesting topics in laser damage: thin films; surfaces, mirrors and contamination; fundamental mechanisms; materials and measurements. This year program was perfected by a minisymposium with the title "To high power limits of fiber lasers" which was organized by Leonid Glebov (University of Central Florida, The College of Optics and Photonics, United States). Dr. Gregory J. Exarhos (Pacific Northwest National Lab., United States), Dr. Vitaly Gruzdev, Dr. Joseph A. Menapace, Dr. Detlev Ristau (Laser Zentrum Hannover e.V., Germany), and Dr. MJ Soileau co-chaired the symposium. The founding organizers of the conference, which was first held in 1969, were Dr. Arthur H. Guenther and Dr. Alexander J. Glass.

Again, many representatives from the international scientific community in the field of laser damage convened to discuss recent results, trends and developments in the four main topics observed within the conference. In the following some statistical aspects of the conference will be presented, and the major scientific trends will summarized in a few paragraphs. 


\section{Statistics of the Conference}

A very high number, 88 papers were accepted for presentation at this meeting (compared to 86 in 2012 and 82 in 2011); however as a consequence of visa and other restrictions, 9 presentations were cancelled. In summary, a total of 80 contributions were presented including one late submission (improvement by 6 papers as compared to 2012). Compared to 2012 , a small reduction in the attendee quota from 157 down to 142 was observed for the $45^{\text {th }}$ symposium, which is mainly attributed to the present funding situation in laser related research and the ongoing consolidation of industrial companies to ever increasing business units. Even though the conference is traditionally organized at the National Institute of Standards and Technology, Boulder, Colorado in the United States, the majority of the contributions (about $58 \%$ ) were submitted by research groups and industrial companies from abroad. This clearly indicates the internationality of the conference which is also reflected by the high number of attendees (around 60) from other countries, among them China, France, Germany, Japan and many others. The 2013 Laser Damage Symposium was again a vivid platform for the interchange of recent research results, as well as for scientific communication and networking in the field. This is also expected for the upcoming 46 $6^{\text {th }}$ Annual Symposium on Optical Materials for High-Power Lasers, which will be held in Boulder, Colorado, one week earlier than the regular cycle, 14-17 September 2014. This event will again feature a series of non-parallel sessions on the traditional topics and a mini-symposium on thermal management in high power lasers and components. The prospective invited talks will cover recent developments in the four major topical areas and the mini-symposium. We look forward to this future opportunity to come together again.

For a more detailed discussion of the development of the conference over the past decades, a summary on the number of attendees and presented papers is depicted in figure 1. These statistics can also be considered as a basis for an assessment of the laser damage topic complementing the rapid progresses in high power laser technology. Obviously, the highest interest in the topic indicated by the number of participants dates back to the 1980's, when some principal obstacle in the development of high power optical thin film systems had to be overcome. During this time period a strong community of many research groups in the field of optical coatings was active and performed an enormous variety of investigations in thin film materials, coating designs, deposition processes and their optimization. At the beginning of the 1990's, a substantial knowledge basis had been created in this field allowing the realization of high power coating systems with significantly improved laser damage thresholds. As a consequence, many companies and research institutes reduced their efforts in this field, and several research groups moved their focus to other areas. This trend is also reflected by the drop in attendance at the beginning of the 1990's. However, besides optical coating problems, a broad spectrum of challenges on the way towards laser components with ever increasing power handling capability remained. In this context, especially the measurement of laser induced damage thresholds and other quality parameters of optical coatings have to be mentioned. The progress in the quality of components as in, for example, optical losses, precise transfer characteristics and power handling capability called for a new generation of improved measurement tools and accompanying international measurement standards. Among others, developments in this field subsisted the Boulder conference over the last decade of the past millennium and lead to a complete set of qualified measurement techniques, as well as to a series of ISO-Standards covering measurement practices for absorption losses, optical scattering, spectral transfer characteristics, laser induced damage thresholds and many other parameters. During the last decade, the conference has been mainly affected by challenges related to the diversification of laser technology and its applications, as well as by the implementation of national high power laser facilities for fundamental research and laser fusion as, for example, the National Ignition Facility (NIF) of the United States, or the Project Mégajoule in France. In summary, the topic of laser induced damage was always a major issue in the development of modern laser technology and will persist in the course of the trend to ever increasing output power, beam quality and packing density of advanced laser systems. Finally, it is quite interesting to note that the number of presented papers in relation to the number of attendees kept consistency over the last 20 years indicating the continuous interest in the field of laser damage. This balanced condition is also based on the number of contributions from abroad, which increased drastically and transformed the symposium to an international conference early in the 1990's (see fig. 2). 


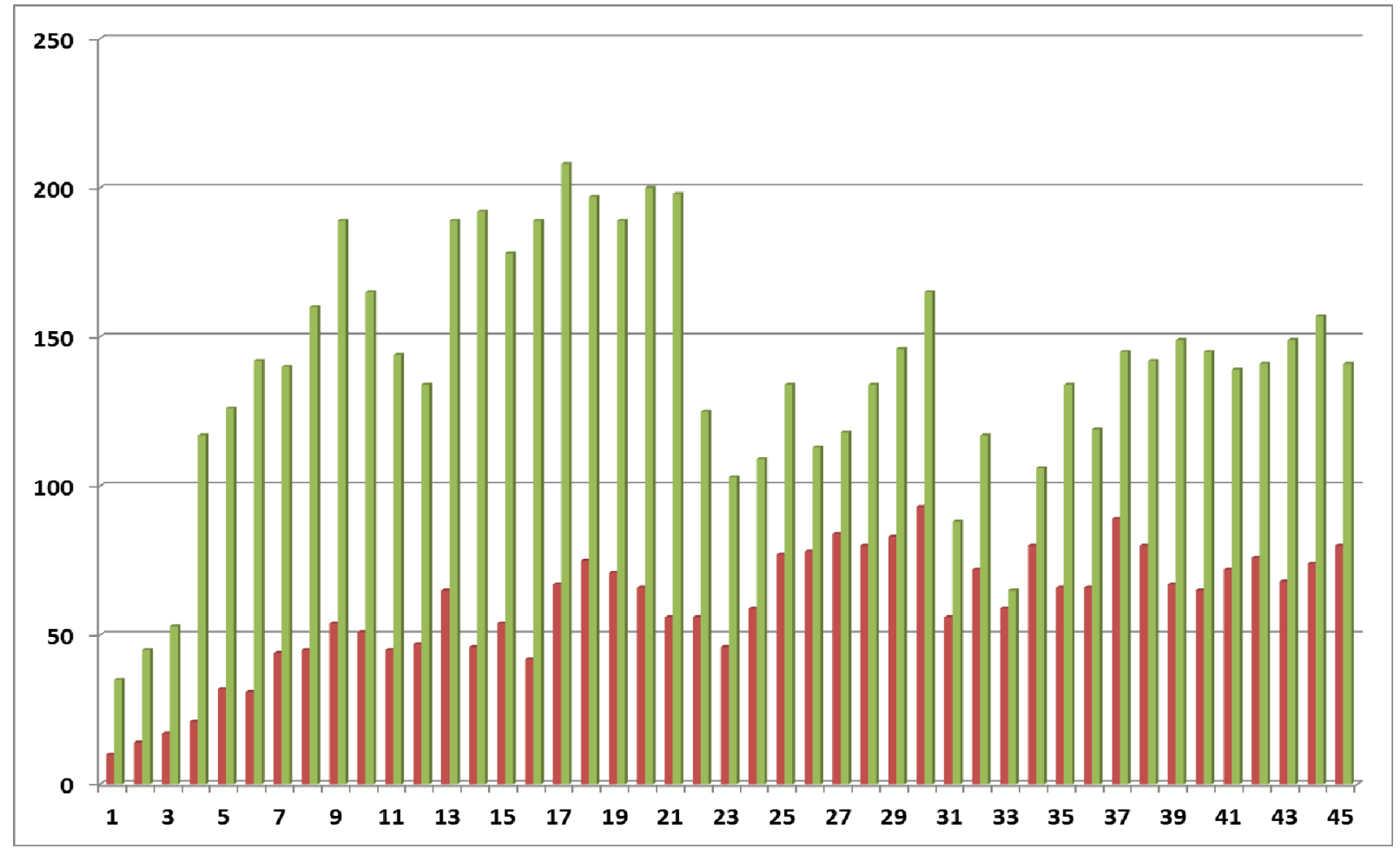

Figure 1: Registered participants and number of presented papers since 1969 including the $45^{\text {th }}$ Laser Damage Symposium 2013 . First column per year - presentations; second column - participants.

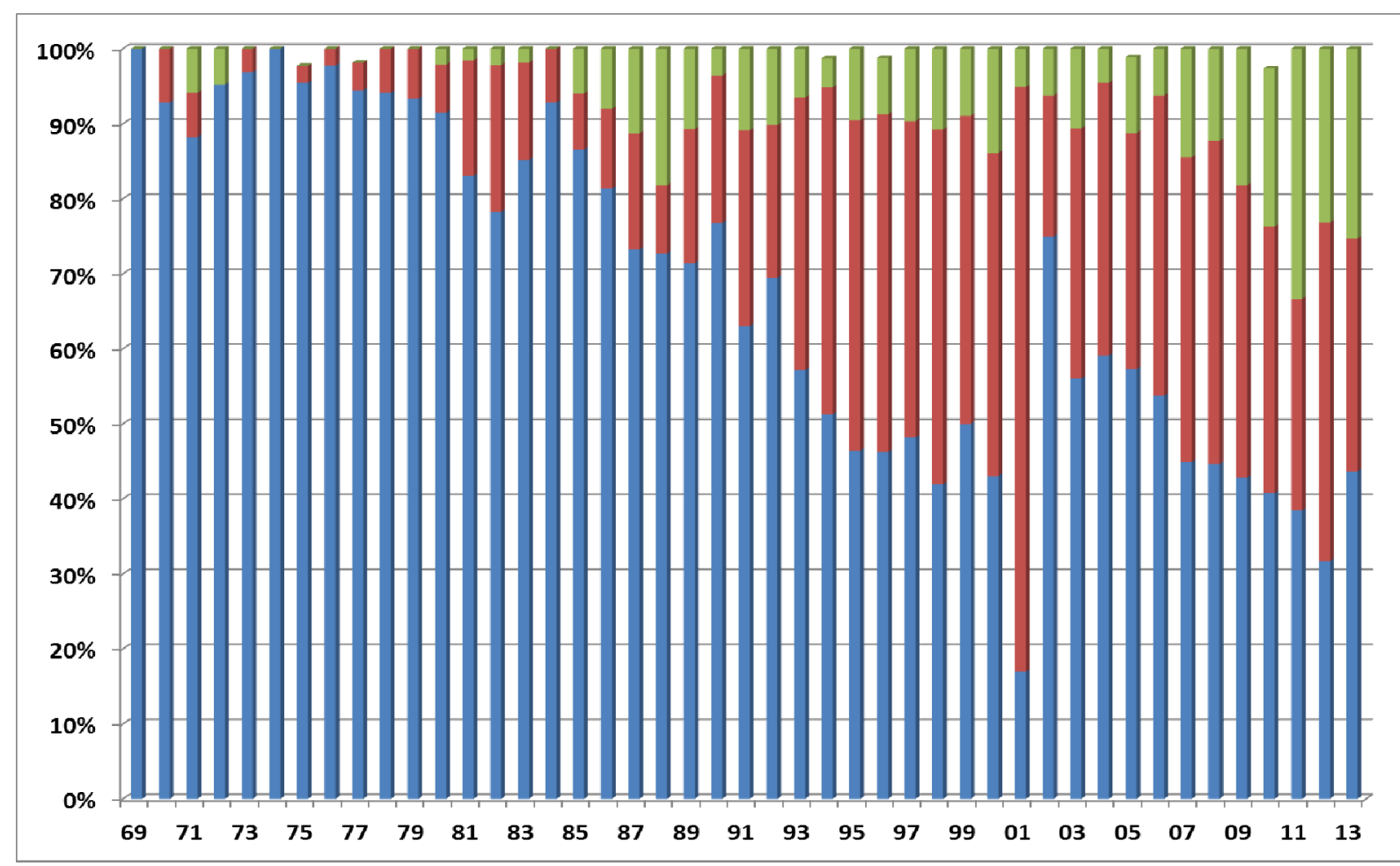

Figure 2: Distribution of contributed papers by continents from 1969. From bottom to top: bottom - North America; second Europe; top: - Asia. 
The Laser (formerly, Boulder) Damage Symposium started as a national workshop and was founded by Dr. A. H. Guenther and Dr. Alexander Glass in the year 1969. As a consequence of the strong interest in the field and related growth of the conference, many scientists within the high-power laser community have contributed significantly as cochairs to the conference during the past 45 years. A historical timeline of their contributions is listed below:

$\begin{array}{ll}1969 & \text { A. H. Guenther, and A. J. Glass (C. M. Stickley) } \\ 1979 & \text { add H. E. Bennett and B. E. Newnam } \\ 1981 & \text { add D. Milam; A. J. Glass departs } \\ 1987 & \text { add MJ Soileau } \\ 1988 & \text { D. Milam departs } \\ 1989 & \text { add L. L. Chase } \\ 1994 & \text { add M. R. Kozlowski; L. L. Chase departs } \\ 1997 & \text { add G. J. Exarhos and K. L. Lewis; H. E. Bennett and B. E. Newnam depart } \\ 2001 & \text { add C. J. Stolz } \\ 2002 & \text { add N. Kaiser; M. R. Kozlowski departs } \\ 2004 & \text { N. Kaiser departs } \\ 2005 & \text { add D. Ristau } \\ 2007 & \text { A. H. Guenther deceased } \\ 2008 & \text { K. L. Lewis departs } \\ 2009 & \text { add V. Gruzdev } \\ 2010 & \text { add J. A. Menapace; C. J. Stolz departs }\end{array}$

\section{Executive Summary}

A survey of the distribution of presentations by topical area is shown in figure 3. During the 2013 conference the highest number of presented contributions (34) was dedicated to the topic "Materials and Measurements" following the trend of the previous years. Compared to the 2012 conference the research area "Surfaces, Mirrors, and Contamination" gained significantly in importance with 17 presentations. A minute reduction of contributions in respect to 2012 could be observed for the topics "Thin Films" and "Fundamental mechanisms." The regular topics were complemented by four papers devoted to the mini-symposium on high power fiber lasers and a special talk presented by Christopher J. Stolz (Lawrence Livermore National Lab., United States) summarizing the results of the laser damage competition on Brewster angle polarizing beam splitters. In the following, the mentioned topics will be addressed in order of their appearance during the conference.

3.1 Thin Films: This topic was introduced by an invited talk on the role of defects in multilayer mirrors and their production for the NIF presented by Christopher J. Stolz. After a brief outline of the historical development of high power mirrors including the results of material studies, laser conditioning and defect removal, the author concentrated on new methods involving the consecutive deposition of overcoats and ion etching steps for a planarization of optical surfaces. This method is based on the angular dependent etching rate of oxide materials employed for the overcoat and results in a significant reduction of the nodule height in laser mirrors. Defects artificially introduced into a coating structure could be effectively smoothened resulting in an increase of the Laser Induced Damage Threshold (LIDT) to more than $100 \mathrm{~J} / \mathrm{cm}^{2}$ for single pulses of $10 \mathrm{~ns}$ duration at the wavelength $1.064 \mu \mathrm{m}$. Defects in coatings were also in the focus of the subsequent contributed presentations clearly demonstrating the increasing importance of this subject in research. For example, Semyon Papernow (University of Rochester, United States), discussed the effect of nanoscale defects $(<100 \mathrm{~nm})$ in $\mathrm{HfO}_{2}$-coatings on fused silica. These defects were investigated with photothermal heterodyne imaging employing a pump laser operating at a wavelength of $355 \mathrm{~nm}$. A very interesting outcome of the paper was the reduction of absorption by irradiation of the samples with power density of up to $1 \mathrm{MW} / \mathrm{cm}^{2}$ from a cw-laser at the wavelength $355 \mathrm{~nm}$. This permanent change of up to $70 \%$ in absorption was attributed to the depopulation of oxygen vacancy states in the hafnia. In this context, the concept and advancements of photothermal microscopy were addressed also by the group of Wolfgang Rudolph (University of New Mexico, United States). As a further interesting topic, Xinbin Cheng (Tongji University, China), considered the effects of mechanical interface strength in $\mathrm{Ta}_{2} \mathrm{O}_{5} / \mathrm{SiO}_{2-}$ multilayers on the laser damage behavior in the ns-pulse duration regime. He could identify a lower strength level for the interface $\mathrm{SiO}_{2} / \mathrm{Ta}_{2} \mathrm{O}_{5}$ compared to the interface $\mathrm{Ta}_{2} \mathrm{O}_{5} / \mathrm{SiO}_{2}$ and interpreted this in the context of his LIDT-tests. Further interesting work on thin film mixtures and the wavelength dependence of LIDT was presented by research groups from Lithuania (Simonas Kitas, Instiute of Physics, Vilnius University) and France (Mireille Commandre, Institut 
Fresnel). These contributions summarized and complemented the knowledge recently gained on the damage behavior of oxide mixtures in the fs- and ns-pulse duration regime. In contrast to the past conferences interest in coatings for the ultra-short pulse regime faded slightly whereas coating defects continue to be an area of intensive research activities with focus on mitigation strategies and process optimization as well as on detection techniques and post treatment effects.

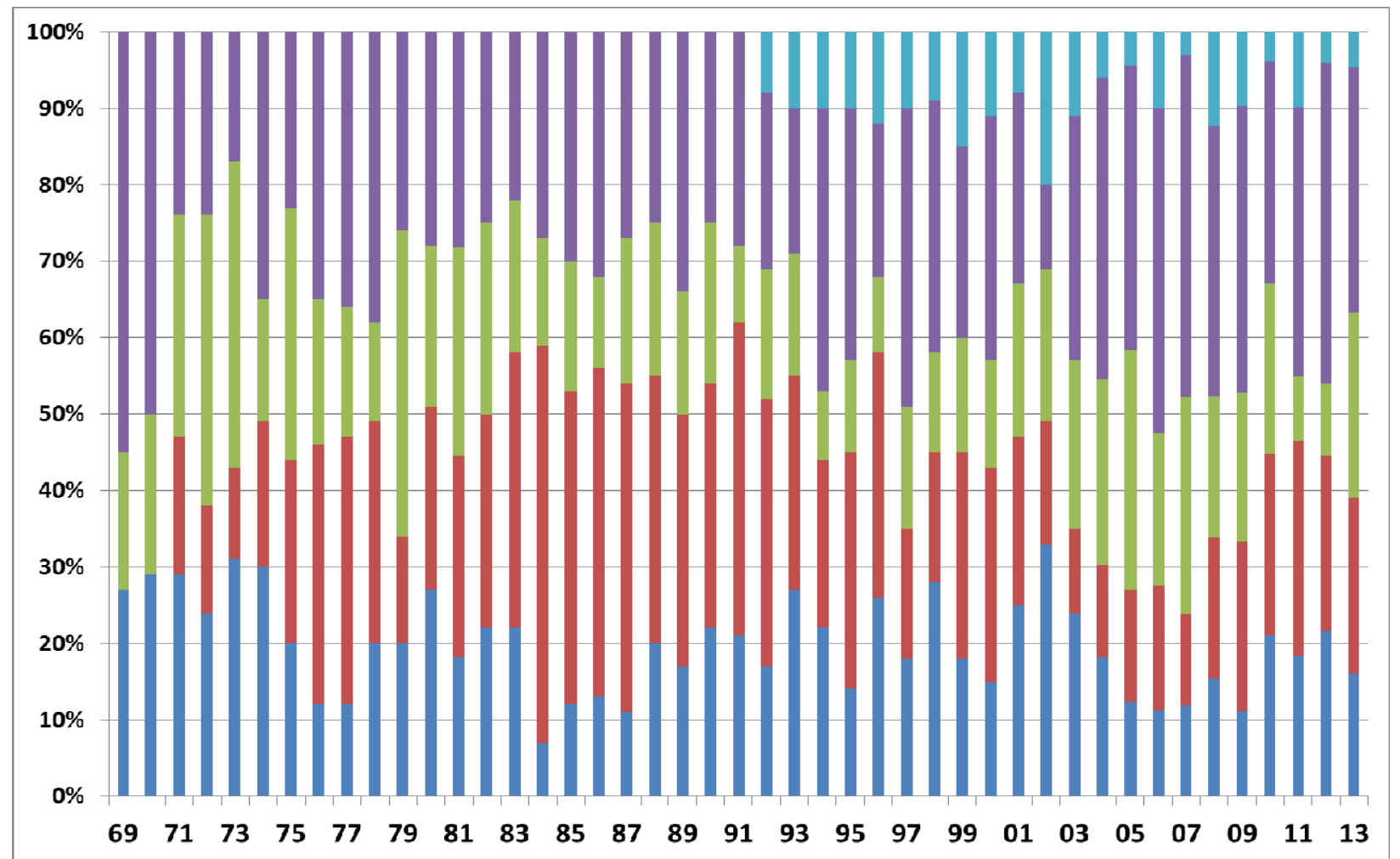

Figure 3: Distribution of presentations by topical area since 1969. From bottom to top: bottom - Fundamental Mechanisms; second - Thin Films; third-Surface, Mirrors, and Contamination; forth - Materials and Measurements; top: - Mini-Symposium.

3.2 Materials and Measurements: The category "Materials and Measurements" was spearheaded by an invited talk on the on status and future capabilities of the National Ignition Facility presented by Paul J. Wagner (Lawrence Livermore National Lab., United States). He summarized the major achievements of the NIF attained since the first operation of this Megajoule class solid state laser starting with around $1 \mathrm{MJ}$ to the present level of $1.8 \mathrm{MJ}$. Special attention was paid to the inspection and optimization of the coated optics and to the frequency conversion crystals in the system.

The lifetime of space born optics is still a problem of major concern within the community. This was underlined by a talk presented by Wolfgang Riede (Deutsche Zentrum für Luft- und Raumfahrt e.V., Germany) and Denny Wernham (European Space Research and Technology Ctr., Netherlands), who outlined the specific challenges related to the ESA space missions. A clear recommendation was revealed to perform raster scanning in addition to laser damage tests for the qualification of laser optics. A second talk in this series by Oleg A. Konoplev (Sigma Space Corp., United Statews) was devoted to assessments of optics for a confidence shot lifetime of 1 trillion at orders of magnitude lower fluence levels compared to the intended lifetime of 3 billion shots of the European AELOS mission projected for the fundamental and first two harmonics of the $\mathrm{Nd}$ :YAG-laser. The author presented results of test procedures with 1 million shots and their interpretation before the background of accelerated marathon tests up to 1 trillion shots performed with a high repetition rate laser operated at $600 \mathrm{kHz}$ pulse rate. The measurement and evaluation of threshold values were also subject of vivid discussions within the conference.

Even though the ISO measurement standard for LIDT values, ISO 21254, is virtually accepted by the community still some specific difficulties in the described evaluation are to be considered. For example, the results of a round-robin test dedicated to optics for vacuum applications and an improved data reduction scheme were presented by Lars O. Jensen (Laser Zentrum Hannover e.V., Germany). In this context, the investigations in advanced evaluation techniques for laser damage measurement data by Jonathan W. Arenberg (Northrop Grumman Aerospace Systems, United States) have to 
be mentioned, which propose approaches on the basis of a maximum likelihood estimation. Furthermore, the group of Wolfgang Rudolph (presented by Luke Emmert) revisited techniques for a time resolved transmission measurement of optical components during the course of laser damage. One of the major experimental findings of this study was the observation that the drop in transmission according to the actual event of damage always appeared prior to the temporal maximum of the pulse. The session on materials and measurements featured also studies on defects in coatings exemplified by a comprehensive study performed at Research Electro Optics Inc., United States. This work illustrated by a coworker of the company, Sam Richman, was concentrated on detailed defect statistics and their relation to the damage fluence level. The authors indicated that the major source of defects may be related to the employed ion beam sputtering process and not to the routinely achievable high cleanliness state of the substrate. Surface contamination was considered within a talk of Douglas S. Hobbs (TelAztec LLC, United States), who showed interesting results of antireflective surfaces produced by etching techniques in comparison to sol gel coatings. LIDT values (355 nm, $10 \mathrm{ns,}$ $250 \mu \mathrm{m}$ ) of up to $27.7 \mathrm{~J} / \mathrm{cm}^{2}$ were achieved for the etched surfaces compared to the range of 31,6 to $35,6 \mathrm{~J} / \mathrm{cm}^{2}$ for sol gel coatings. This study was complemented by a contribution on structured optics by an extended research consortium of several universities from the United States.

As a totally different area interest, Paul J. Phillips (Rutherford Appleton Lab., United Kingdom) reported damage thresholds of ceramic Nd:YAG at cryogenic and room temperatures. The authors tested a set of samples with antireflective coatings deposited by different processes for the wavelengths $940 \mathrm{~nm}$ and $1030 \mathrm{~nm}$, respectively. In most cases a significant increase of the measured 1 on 1 LIDT values $(1030 \mathrm{~nm}, 3 \mathrm{~ns}$, top hat profile $250 \mu \mathrm{m})$ was observed for cryogenic temperatures. For example, the front surface of one sample revealed an augmentation in threshold value from $31.4 \mathrm{~J} / \mathrm{cm}^{2}$ at $300 \mathrm{~K}$ room temperature to $61.1 \mathrm{~J} / \mathrm{cm}^{2}$ at a temperature at $105 \mathrm{~K}$.

Not least, a variety of measurement techniques were considered in further contributions, for example based on photothermal methods like photoacoustic spectroscopy, laser calorimetry, common path interferometry or HartmannShack sensors.

In summary, investigations in an improvement of the ISO standard for LIDT testing, ISO 21254, could be detected as one essential trend of the present conference. The extrapolation and assessment of the lifetime of optical components is persisting to be an unsolved problem and still attracts various research efforts. Furthermore, the economic production and power handling capabilities of structured optics continue to play an important role in the research activities. Finally, the detection and classification of defects was also discussed within the materials and measurement area clearly indicating the significance of this problem.

3.3 Surfaces, Mirrors, and Contamination: Sessions on this subject contained several papers on the effect of laser ablated debris and laser induced contamination on the power handling capability of optical surfaces. The session series was opened by an invited talk of James E. Andrew (AWE, United Kingdom), who gave a review on effects of focused high energy lasers beams on a variety of plasma targets. Helmut Schröder (Deutsche Zentrum für Luft- und Raumfahrt e.V., Germany) presented a talk on contaminations naphtalene and anthracene deposited on coated surfaces during laser irradiation in specially prepared environments to assess the growth effects and laser interaction mechanisms of the contamination layers. The experiments were aimed at a laser damage risk mitigation for optical components employed in ALADIN mission and involved damage tests at $355 \mathrm{~nm}$ at a pulse duration of $10 \mathrm{~ns}$. A drastic reduction of the LIDT values to less than $1 \mathrm{~J} / \mathrm{cm}^{2}$ could be observed for contaminated surfaces after a few minutes in an environment containing a partial pressure around $0.3 \mu$ bar of the aromatic hydrocarbons. Further studies in this area were illustrated by a group from the Osaka University (Hidetoshi Murakami, Osaka University, Japan) and other Japanese research centers. This group concentrated on oil contaminations found in the LFEX Laser system at the Osaka University and reported on a decrease of LIDT values by a factor $1 / 2$ during 120 hours of operation under a specially prepared atmosphere of $\mathrm{N}_{2}$ with toluene.

Another remarkable topic of the sessions was the removal of scratches and defects from optical surfaces. Among contributions discussing laser based method, outstanding achievements at the NIF were presented by James A. Folta (Lawrence Livermore National Lab, United States). He introduced the specially established high volume facility for recycling of large NIF optics with laser damage sites. The defect mitigation is achieved on the basis of a $\mathrm{CO}_{2}$-laser irradiation scheme with dynamic beam diameter and adapted spot sizes controlled by an online imaging system. The facility enables a repair rate of up to $98 \%$ and processed already more than 2500 pieces of large scale optics for the NIF. The effects and removal of pre-existing defects and subsurface damage of fused silica were also discussed in several contributions including laser based and magneto-rheological fluid finishing techniques for repair. Within the framework of the development of an ignition facility in China, the influence of scratches with different width on fused silica and plastic surfaces on laser damage thresholds was addressed by a contribution from the Tongji University. The scratches were indented by a diamond tip with different loads in mirror coatings of $\mathrm{HfO}_{2} / \mathrm{SiO}_{2}$ and laser damage tested under different angles of incidence.

xviii 
Besides a variety of specific application oriented research activities, clear tendencies towards a deeper understanding of laser induced contamination effects are of continuous importance within the community. Also, the repair of optical surfaces, scratch removal and advanced cleaning techniques are in the focus of present research activities.

3.4 Fundamental Mechanisms: The topic was introduced by a comprehensive survey on the present knowledge on laser damage in dielectric films prepared by Wolfgang Rudolph. He summarized some major aspects of the role of material properties and defects in damage mechanisms induced by ultra-short up to long laser pulses. Theoretical models on the basis of electron photon interaction schemes could be principally confirmed by many experiments in the fs-pulse regime and indicate a predominance of material properties in laser damage mechanisms. However, for longer pulses, the role of intrinsic mechanisms fades, and thermal effects gain of importance for longer pulse durations in the nanosecond region. In this context, especially defects in the coatings have to be considered as a major origin of damage at fluence values far below the expected intrinsic threshold values of dielectric materials. As a consequence, detailed investigations in the different types of defects appearing in dielectric coatings are an essential prerequisite for further progresses in the power handling capability of coatings for longer pulse durations. The authors presented advanced approaches for analyzing defects in coatings including for example photothermal microscopy techniques, time resolved damage studies, and third harmonic microscopy. Besides several articles dedicated to bulk damage in KTP, borosilicate glass, and fused silica presented by authors from the Lawrence Livermore National Lab, United States, and a consortium of French research groups, a comprehensive study on the dynamics of ultra-short pulse damage was published by groups from Lithuania (Vilnius University) and France (Institut Fresnel). The work presented by Nerijus Siaulys (Vilnius University) was concentrated on digital holographic pump probe experiments to resolve the different interaction phases of ultrashort pulse laser radiation with $\mathrm{Ta}_{2} \mathrm{O}_{5}$ single layers. By tuning the time delay between pump and probe beam, the electron gas generation and plasma dynamics could be recorded, and typical time constants were identified. For example, the highest electron density in the conduction band could be assigned to a time interval of 200 fs, and temperature rises due to lattice heating were observed approximately $1.4 \mathrm{ps}$ after the maximum of the pump pulse $(1,030 \mathrm{~nm}, 300 \mathrm{fs}) \mathrm{had}$ passed the sample. The experimental data were found in accordance with theoretical models describing the damage dynamics. This contribution indicates a trend towards studies in detailed models for damage dynamics in thin films and bulk optical material which was also by other publications within the conference. As a further apparent research topic of high interest in the field of fundamental mechanisms again defects in dielectric materials could be identified reflecting one of the general aspects addressed by many talks and posters.

3.5 Mini-symposium: This year the meeting hosted a special mini-symposium focused on fiber lasers and the problems related to the limited power handling capabilities of fibers and their end faces. The mini-symposium was organized by Leonid Glebov and started with an invited talk considering the maximum achievable output powers and energies of present fiber lasers given by a coworker of IPG Photonics Corp. United States. Within the framework of the symposium among other interesting aspects, results on the damage behavior of polished and cleaved fiber end faces were discussed. A study on cw laser damage at $405 \mathrm{~nm}$ presented by Cornell P. Gonschior (Technische Hochschule Mittelhessen, Germany) indicated the formation of a ripple structure and color centers in the core region of the fiber leading to losses not acceptable for the application.

A brief summary of the past mini-symposium topics starting from 1992 and the organizing chairs is listed below.

\begin{tabular}{|c|c|c|}
\hline Year & Chair & Topic \\
\hline 1992 & Brian Newnam & Damage Issues for Lithographic Optics \\
\hline 1993 & Karl Guenther & $\begin{array}{l}\text { Quest for the Invincible Laser Coating - Critical Review of Pulse Laser-Induced } \\
\text { Damage to Optical Coatings: Causes and Cures }\end{array}$ \\
\hline 1994 & Claude Klein & Diamond for Optics Applications in Adverse Environment \\
\hline 1995 & Floyd Hovis & Contamination and the Laser Damage Process \\
\hline 1996 & Robert Setchell & Laser-Induced Damage in Optical fibers \\
\hline 1997 & David Welch & Damage and Lifetime Issues for Laser diodes \\
\hline 1998 & Norbert Kaiser & Optics for Deep UV \\
\hline 1999 & David Sliney & Laser Damage Processes in the Eye and Other Biological Tissue \\
\hline 2000 & $\begin{array}{l}\text { Mark Kozlowski } \\
\text { Hideo Hosono }\end{array}$ & Defects in Glass \\
\hline 2001 & Mark Kozlowski & Optical Materials for Telecommunications \\
\hline 2002 & Detlev Ristau & $\begin{array}{l}\text { Optics characterization - joint with } 7^{\text {th }} \text { International Workshop of Laser Beam } \\
\text { and Optics characterization }\end{array}$ \\
\hline 2003 & William Latham & Understanding Optical Damage with Ultra-short Laser Pulses \\
\hline
\end{tabular}




$\begin{array}{lll}2004 & \text { Keith Lewis } & \text { Damage Issues in Fiber Laser systems } \\ 2005 & \text { Leon Glebov } & \text { Petawatt Lasers } \\ 2006 & \text { Alan Stewart } & \text { Optics in a Hostile Environment } \\ 2007 & \text { Stan Peplinski } & \text { Lifetime Issues for CW and Quasi-CW Lasers } \\ 2008 & \begin{array}{l}\text { Christopher Stolz } \\ \text { Herve Bercegol }\end{array} & \text { Fused Silica } \\ 2009 & \text { Wolfgang Rudolph } & \text { Femtosecond Laser-Induced Damage } \\ 2010 & \begin{array}{l}\text { Klaus } \\ \text { Sokolowski-Tinten }\end{array} & \text { Fundamentals of Laser Ablation } \\ 2011 & \begin{array}{l}\text { Holger Blashke, } \\ \text { Carmen Menoni }\end{array} & \text { Deep-UV Optics } \\ 2011 & \begin{array}{l}\text { Michelle Shin } \\ \text { Stavros Demos }\end{array} & \text { Meta-Optics/Photonic Band Gap Materials } \\ 2012 & & \text { Laser-Induced Plasma Interactions }\end{array}$

3.6 Laser damage competition: In 2013, the second part of the damage competition on Brewster angle polarizing beamsplitters was presented by the organizer Christopher J. Stolz. The double blind experiment, which was started in 2012 , calling for polarizing beamsplitters with minimum transmission of $95 \%$ at $p$ polarization and minimum reflection of $99 \%$ at $s$ polarization at $1064 \mathrm{~nm}$ under 56.4 degrees angle of incidence. Several companies and institutes from the United States, Europe, China, and Japan sent in samples, which were tested with 20 ns pulses at the laser-damage test facility of Quantel, United States. The presentation complemented the work on p-polarization performed in 2012 by the LIDT data on s-polarization. A few samples were additionally sent in and integrated in the experiment in 2013 . The results indicate interesting relations between the threshold values and the multitude of deposition processes, coating materials, and manufacturing techniques involved in this competition. The present test was the last in a row of several competitions started on the occasion of the $40^{\text {th }}$ anniversary of the conference:

$\begin{array}{ll}2008 & \text { HR-mirror for Nd:YAG-laser, } 1.064 \mathrm{~nm}, \text { ns-regime } \\ 2009 & \text { HR-mirror for Ti:Sapphire laser, 780nm, fs-regime } \\ 2010 & \text { AR-coating for Excimer, 351nm, ns-regime } \\ 2011 & \text { HR-mirror for Excimer, } 193 \mathrm{~nm}, \text { ns-regime } \\ 2012 & \text { Brewster angle thin film polarizer, 1.064nm, ns-regime, "p-polarisation" } \\ 2013 & \text { Brewster angle thin film polarizer, 1.064nm, ns-regime, "s-polarisation" }\end{array}$

For the upcoming laser damage conference in 2014, a thin film Fabry-Perot filter for the Nd:YAG-laser wavelength damage tested in the ns-regime will be considered.

3.6 Summary: Again, the 2013 Laser Damage Conference hosted an enormous variety of valuable and high quality contributions, all of which cannot be considered in this short synopsis, clearly indicating the high actuality of the tropic and continuous research effort performed by many research groups all over the world. Recording major trends, especially the role of defects in laser damage, contamination effects and the repair of surfaces have to be mentioned among many others. 


\section{Plenary Talks}

The 45th Laser Damage Symposium is highlighted by several invited presentations introducing the major topics of the conference:

Defect insensitive $100 \mathrm{~J} / \mathrm{cm}^{2}$ multilayer mirror coating process

Christopher J. Stolz, Justin E. Wolfe, Paul B. Mirkarimi, James A. Folta, John J. Adams, Marlon G. Menor, Nick E.

Teslich, Regina Soufli, Lawrence Livermore National Lab. (United States); Carmen S. Menoni, Dinesh Patel, Colorado State Univ. (United States)

National Ignition Facility laser performance: status and thoughts on future capabilities

Paul J. Wegner, Lawrence Livermore National Lab. (United States)

A review of laser target debris and shrapnel studies by $A W E$

James E. Andrew, AWE plc (United Kingdom)

Feasibility of maximum acbievable powers and energies in fiber lasers

IPG Photonics Corp. (United States)

Laser damage in dielectric films: What we know and what we don't

Wolfgang Rudolph, Luke A. Emmert, The Univ. of New Mexico (United States); Carmen S. Menoni, Dinesh Patel,

Colorado State Univ. (United States)

\section{Conference Awards}

Beginning with the meeting in 2000, the organizers instituted a best paper award in the oral and poster categories. The awards appropriately take the form of laser-induced art in an optical glass plaque. (see, e.g., paper by I. N. Trotski, Proc. SPIE 4679, 392-399 (2001)). Among many outstanding posters and oral papers the following papers were selected:

Best oral paper:

Application of time-resolved digital holographic microscopy to study femtosecond damage process in thin films Nerijus Siaulys, Andrius Melninkaitis, Vilnius Univ. (Lithuania); Laurent Gallais-During, Institut Fresnel (France)

Best poster paper:

Dependence of fs laser resistance of optical materials on wavelength Laurent Gallais-During, Dam-Be L. Douti, Institut Fresnel (France); Gintare Bataviciute, Egidijus Pupka, Mindaugas Šciuka, Linas Smalakys, Andrius Melninkaitis, Vilnius Univ. (Lithuania); Fabien Lemarchand, Institut Fresnel (France); Valdas Sirutkaitis, Vilnius Univ. (Lithuania); Mireille Commandre, Institut Fresnel (France)

\section{Acknowledgments}

A number of volunteers help tirelessly with some of the administrate duties necessary to put on a conference of this magnitude. Atrica Lal from Lawrence Livermore National Lab. helped with the registration pick up and at front desk through the entire meeting. Artika Arpana from Lawrence Livermore National Lab. assisted with the thin-film competition. Thanks also to the SPIE staff for their assistance with administrative, program, and proceedings planning.

This year we acknowledge support from local Colorado companies: ATFilms, Arrow Thin Films, Alpine Research Optics, and Precision Photonics Corp. as well as the Laboratory for Laser Energetics in Rochester (all United States) for supporting the social events of this meeting as well as support from the cosponsors Lawrence Livermore National Laboratory and Spica Technologis Inc. Special thanks also to Quantel for performing the enormous work on damage testing for the competition. 
Of course, we are all indebted to Kent Rochford, Division Chief of the Optoelectronics Division, who was the prime contact at NIST, for his continued support, encouragement, and especially for the organization of NIST tours, as well as Jason Day, also of NIST, who worked really great with the audio equipment and made the oral sessions running smooth. On behalf of all the organizers and attendees, we thank them for their tireless efforts.

\section{References}

\section{Books:}

A. J. Glass and A. H. Guenther, eds. Damage in Laser Glass, ASTM Spec. Tech. Pub. 469, ASTM, Philadelphia, PA (1969). N. Bloembergen, Fundamentals of Damage in Laser Glass, National Materials Advisory Board Publ. NMAB-271, National Academy of Sciences (1970).

N. Bloembergen, High-Power Infrared Laser Windows, National Materials Advisory Board Publ. NMAB-356 (1971).

R. M. Wood, Laser-Induced Damage in Optical Materials, Adam Hilger, Bristol (UK) (1986).

M. J. Weber, ed., Handbook of Laser Science and Technology, Vol. III: Optical Materials, Part 1: Nonlinear Optical Properties/Radiation Damage, CRC, Boca Raton, FL (1986).

M. J. Weber, ed., Handbook of Laser Science and Technology, Vol. IV: Optical Materials, Part 2: Properties, CRC, Boca Raton, FL (1986).

M. J. Weber, ed., Handbook of Laser Science and Technology, Vol. V: Optical Materials, Part 3: Applications, Coatings, and Fabrication, CRC, Boca Raton, FL (1987).

R. M. Wood, Ed., Selected Papers on Laser Damage in Optical Materials, SPIE Milestone Series Vol. MS24, Bellingham, WA (U.S.) (1990).

M. R. Kozlowski, Damage-Resistant Laser Coatings, in Thin Films for Optical Systems, F. Flory, ed., Marcel Dekker, New York, 521-549 (1995).

M. J. Weber, ed., Handbook of Laser Science and Technology, Suppl. 2, Optical Materials, CRC, Boca Raton, FL, (1995).

A. H. Guenther, ed., International Trends in Applied Optics, SPIE Press monograph, Bellingham, Washington, Chapters 1, 3, $8,9,10, \& 12$ (2002).

M. J. Weber, ed., Handbook of Optical Materials, CRC, Boca Raton, FL (2002).

R. M. Wood, The Power and Energy-Handling Capability of Optical Material, Components, and Systems, (Tutoriual Texts in Optical Engineering Vol TT60 A. R. Weeks Series Editor SPIE Press Bellingham WA) (2003).

R. M. Wood, Laser Induced Damage of Optical Materials (Institute of Physics Publishing, Bistrol, UK) (2003).

C. J. Stolz and F. Y. Génin, Laser Resistant Coatings, in Optical Interference Coatings, N. Kaiser and H. Pulker, eds., Springer-Verlag, Berlin, 310-333 (2003).

D. Ristau, Laser Damage in Thin Film Filters. Encyclopedia of Modern Optics. Elsevier, Oxford, ISBN 0-12-227600-0. (2004)

\section{Proceedings:}

A. J. Glass and A. H. Guenther, eds., Damage in Laser Materials, Nat. Bur. Stand. (U.S.) Spec. Publ. 341 (1970).

A. J. Glass and A. H. Guenther, Eds., Damage in Laser Materials: 1971, Nat. Bur. Stand. (U.S.) Spec. Publ. 356 (1971).

A. J. Glass and A. H. Guenther, eds., Laser-Induced Damage in Optical Materials: 1972, Nat. Bur. Stand. (U.S.) Spec. Publ. 372 (1972).

A. J. Glass and A. H. Guenther, Eds., Laser-Induced Damage in Optical Materials: 1973, Nat. Bur. Stand. (U.S.) Spec. Publ. 387 (1973).

A. J. Glass and A. H. Guenther, eds., Laser-Induced Damage in Optical Materials: 1974, Nat. Bur. Stand. (U.S.) Spec. Publ. 414 (1974).

A. J. Glass and A. H. Guenther, eds., Laser-Induced Damage in Optical Materials: 1975, Nat. Bur. Stand. (U.S.) Spec. Publ. 435 (1975).

A. J. Glass and A. H. Guenther, eds., Laser-Induced Damage in Optical Materials: 1976, Nat. Bur. Stand. (U.S.) Spec. Publ. 462 (1976).

A. J. Glass and A. H. Guenther, eds., Laser-Induced Damage in Optical Materials: 1977, Nat. Bur. Stand. (U.S.) Spec. Publ. 509 (1977).

A. J. Glass and A. H. Guenther, eds., Laser-Induced Damage in Optical Materials: 1978, Nat. Bur. Stand. (U.S.) Spec. Publ. 541 (1978).

H. E. Bennett, A. J. Glass, A. H. Guenther, and B. E. Newnam, eds., Laser-Induced Damage in Optical Materials: 1979 , Nat. Bur. Stand. (U.S.) Spec. Publ. 568 (1979). 
H. E. Bennett, A. J. Glass, A. H. Guenther, and B. E. Newnam, eds., Laser-Induced Damage in Optical Materials: 1980 , Nat. Bur. Stand. (U.S.) Spec. Publ. 620 (1981).

H. E. Bennett, A. J. Glass, A. H. Guenther, and B. E. Newnam, eds., Laser-Induced Damage in Optical Materials: 1981, Nat. Bur. Stand. (U.S.) Spec. Publ. 638 (1983).

H. E. Bennett, A. H. Guenther, D. Milam, and B. E. Newnam, eds., Laser-Induced Damage in Optical Materials: 1982, Nat. Bur. Stand. (U.S.) Spec. Publ. 669 (1984).

H. E. Bennett, A. H. Guenther, D. Milam, and B. E. Newnam, eds., Laser-Induced Damage in Optical Materials: 1983 , Nat. Bur. Stand. (U.S.) Spec. Publ. 688 (1985).

H. E. Bennett, A. H. Guenther, D. Milam, and B. E. Newnam, eds., Laser-Induced Damage in Optical Materials: 1984, Nat. Bur. Stand. (U.S.) Spec. Publ. 727 (1986).

H. E. Bennett, A. H. Guenther, D. Milam, and B. E. Newnam, eds., Laser-Induced Damage in Optical Materials: 1985, Nat. Bur. Stand. (U.S.) Spec. Publ. 746 (1987).

H. E. Bennett, A. H. Guenther, D. Milam, and B. E. Newnam, eds., Laser-Induced Damage in Optical Materials: 1986, Nat. Bur. Stand. (U.S.) Spec. Publ. 752 (1987).

H. E. Bennett, A. H. Guenther, D. Milam, B. E. Newnam, and M. J. Soileau, eds., Laser-Induced Damage in Optical Materials: 1987, Nat. Bur. Stand. (U.S.) Spec. Publ. 756 (1988).

H. E. Bennett, A. H. Guenther, B. E. Newnam, and M. J. Soileau, eds., Laser-Induced Damage in Optical Materials: 1988, Nat. Bur. Stand. (U.S.) Spec. Publ. 775 (1989).

H. E. Bennett, L. L. Case, A. H. Guenther, B. E. Newnam, and M. J. Soileau, eds., Laser-Induced Damage in Optical Materials: 1989, NIST (U.S.) Spec. Publ. 801, ASTM STP 1117 and Proc. SPIE 1438 (1989).

H. E. Bennett, L. L. Case, A. H. Guenther, B. E. Newnam, and M. J. Soileau, eds., Laser-Induced Damage in Optical Materials: 1990, ASTM STP 1141 and Proc. SPIE 1441 (1991).

H. E. Bennett, L. L. Case, A. H. Guenther, B. E. Newnam, and M. J. Soileau, eds., Laser-Induced Damage in Optical Materials: 1991, Proc. SPIE 1624 (1992).

H. E. Bennett, L. L. Case, A. H. Guenther, B. E. Newnam, and M. J. Soileau, eds., Laser-Induced Damage in Optical Materials: 1992, Proc. SPIE 1848 (1993).

H. E. Bennett, L. L. Case, A. H. Guenther, B. E. Newnam, and M. J. Soileau, eds., Laser-Induced Damage in Optical Materials: 1993, Proc. SPIE 2114 (1994).

H. E. Bennett, A. H. Guenther, M. R. Kozlowski, B. E. Newnam, and M. J. Soileau, eds., Laser-Induced Damage in Optical Materials: 1994, Proc. SPIE 2428 (1995).

H. E. Bennett, A. H. Guenther, M. R. Kozlowski, B. E. Newnam, and M. J. Soileau, eds., Laser-Induced Damage in Optical Materials: 1995, Proc. SPIE 2714 (1996).

H. E. Bennett, A. H. Guenther, M. R. Kozlowski, B. E. Newnam, and M. J. Soileau, eds., Laser-Induced Damage in Optical Materials: 1996, Proc. SPIE 2966 (1997).

G. J. Exarhos, A. H. Guenther, M. R. Kozlowski, and M. J. Soileau, eds., Laser-Induced Damage in Optical Materials: 1997, Proc. SPIE 3244 (1998).

G. J. Exarhos, A. H. Guenther, M. R. Kozlowski, K. Lewis, and M. J. Soileau, eds., Laser-Induced Damage in Optical Materials: 1998, Proc. SPIE 3578 (1999).

G. J. Exarhos, A. H. Guenther, M. R. Kozlowski, K. Lewis, and M. J. Soileau, eds., Laser-Induced Damage in Optical Materials: 1999, Proc. SPIE 3902 (2000).

G. J. Exarhos, A. H. Guenther, M. R. Kozlowski, K. Lewis, and M. J. Soileau, eds., Laser-Induced Damage in Optical Materials: 2000, Proc. SPIE 4347 (2001).

G. J. Exarhos, A. H. Guenther, K. Lewis, M. J. Soileau, and C. J. Stolz eds., Laser-Induced Damage in Optical Materials: 2001, Proc. SPIE 4679 (2002).

G. J. Exarhos, A. H. Guenther, K. Lewis, N. Kaiser, M. J. Soileau, and C. J. Stolz eds., Laser-Induced Damage in Optical Materials: 2002, Proc. SPIE 4932 (2003).

G. J. Exarhos, A. H. Guenther, K. Lewis, N. Kaiser, M. J. Soileau, and C. J. Stolz eds., Laser-Induced Damage in Optical Materials: 2003, Proc. SPIE 5273 (2004).

G. J. Exarhos, A. H. Guenther, K. Lewis, N. Kaiser, M. J. Soileau, and C. J. Stolz eds., Laser-Induced Damage in Optical Materials: 2004, Proc. SPIE 5647 (2005).

G. J. Exarhos, A. H. Guenther, K. Lewis, D. Ristau, M. J. Soileau, and C. J. Stolz eds., Laser-Induced Damage in Optical Materials: 2005, Proc. SPIE 5991 (2006).

G. J. Exarhos, A. H. Guenther, K. Lewis, D. Ristau, M. J. Soileau, and C. J. Stolz eds., Laser-Induced Damage in Optical Materials: 2006, Proc. SPIE 6403 (2007).

G. J. Exarhos, D. Ristau, M. J. Soileau, and C. J. Stolz eds., Laser-Induced Damage in Optical Materials: 2007, Proc. SPIE 6720 (2008). 
G. J. Exarhos, D. Ristau, M. J. Soileau, and C. J. Stolz eds., Laser-Induced Damage in Optical Materials: 2008, Proc. SPIE $7132(2009)$.

G. J. Exarhos, V. E. Gruzdev, D. Ristau, M. J. Soileau, and C. J. Stolz eds., Laser-Induced Damage in Optical Materials: 2009, Proc. SPIE 7504 (2010).

G. J. Exarhos, V. E. Gruzdev, J. A. Menapace, D. Ristau, and M. J. Soileau, eds., Laser-Induced Damage in Optical Materials: 2010, Proc. SPIE 7842 (2011).

G. J. Exarhos, V. E. Gruzdev, J. A. Menapace, D. Ristau, and M. J. Soileau, eds., Laser-Induced Damage in Optical Materials: 2011, Proc. SPIE 8190 (2012).

G. J. Exarhos, V. E. Gruzdev, J. A. Menapace, D. Ristau, and M. J. Soileau, eds., Laser-Induced Damage in Optical Materials: 2012, Proc. SPIE 8530 (2013).

\section{Compact Discs:}

A. H. Guenther, ed., Laser-Induced Damage in Optical Materials: Collected papers 1969-1998 (a three CD-ROM set available from SPIE, P.O. Box 10, Bellingham, WA 98227-0010) (1999).

A. H. Guenther, ed., Laser-Induced Damage in Optical Materials: Collected papers 1999-2003 (CD-ROM available from SPIE, P.O. Box 10, Bellingham, WA 98227-0010) (2004).

Selected SPIE Papers on CD-ROM: Laser-Induced Damage in Optical Materials. 1969-2008: 40 years of Boulder Damage Symposium, v. 50 (CD-ROM available from SPIE, P.O. Box 10, Bellingham, WA 98227-0010) (2008).

Selected SPIE Papers on CD-ROM: Laser-Induced Damage in Optical Materials. Collected Papers, 2009-2010, v. 52 (CD-ROM available from SPIE, P.O. Box 10, Bellingham, WA 98227-0010) (2010).

\section{Journal articles:}

A. J. Glass and A. H. Guenther, eds., Laser-Induced Damage in Optical Materials: A conference Report, Appl. Opt. 13 (1): $74-88$ (1974).

A. J. Glass and A. H. Guenther, eds., Laser-Induced Damage in Optical Materials: $6^{\text {th }}$ ASTM Symposium, Appl. Opt. 14 (3): 698-715 (1975).

A. J. Glass and A. H. Guenther, eds., Laser-Induced Damage in Optical Materials: $7^{\text {th }}$ ASTM Symposium, Appl. Opt. 15 (6): 1510-1529 (1976).

A. J. Glass and A. H. Guenther, eds., Laser-Induced Damage in Optical Materials:8 ${ }^{\text {th }}$ ASTM Symposium, Appl. Opt. 16 (5): 1214-1231 (1977).

A. J. Glass and A. H. Guenther, eds., Laser-Induced Damage in Optical Materials: $9^{\text {th }}$ ASTM Symposium, Appl. Opt. 17 (6): 2386-2411 (1978).

A. J. Glass and A. H. Guenther, eds., Laser-Induced Damage in Optical Materials: $10^{\text {th }}$ ASTM Symposium, Appl. Opt. 18 (13): 2212-2229 (1979).

H. E. Bennett, A. J. Glass, A. H. Guenther, and B. E. Newnam, eds., Laser-Induced Damage in Optical Materials: $11^{\text {th }}$ ASTM Symposium, Appl. Opt. 19 (14): 2375-2397 (1980).

H. E. Bennett, A. J. Glass, A. H. Guenther, and B. E. Newnam, eds., Laser-Induced Damage in Optical Materials: $12^{\text {th }}$ ASTM Symposium, Appl. Opt. 20 (17): 3003-3019 (1981).

H. E. Bennett, A. H. Guenther, D. Milam, and B. E. Newnam, eds., Laser-Induced Damage in Optical Materials: $13^{\text {th }}$ ASTM Symposium, Appl. Opt. 22 (20): 3276-3296 (1983).

H. E. Bennett, A. H. Guenther, D. Milam, and B. E. Newnam, eds., Laser-Induced Damage in Optical Materials: $14^{\text {th }}$ ASTM Symposium, Appl. Opt. 23 (21): $3782-3795$ (1984).

H. E. Bennett, A. H. Guenther, D. Milam, and B. E. Newnam, eds., Laser-Induced Damage in Optical Materials: $15^{\text {th }}$ ASTM Symposium, Appl. Opt. 25 (2): 258-275 (1986).

H. E. Bennett, A. H. Guenther, D. Milam, and B. E. Newnam, eds., Laser-Induced Damage in Optical Materials: $16^{\text {th }}$ ASTM Symposium, Appl. Opt. 26 (5): 813-827 (1987).

A. H. Guenther, "Optics damage constrains laser design and performance," Laser Focus World, 29, 83-87, 1992.

A. H. Guenther, "Previewing the Boulder Damage Symposium," Lasers and Optronics 12, 25-26,1993.

A. H. Guenther, "Laser-Induced Damage in Optical Materials at the October 6-8, 1997 Symposium on Optical Materials for High-Power Lasers (Boulder Damage Symposium), Boulder, Colorado” J. Laser Appl. 9, 261-266,1997. 


\title{
Summary of Round Table Discussion - 2013
}

\author{
Vitaly E. Gruzdev \\ Department of Mechanical and Aerospace Engineering, University of Missouri \\ Columbia, MO 65211, USA
}

A recently established tradition of Laser Damage Symposium is a Roundtable Discussion held as a pre-symposium event of Sunday evening during registration. For the first time, the Roundtable discussion was held in 2009 with the purpose of intellectual warming up for symposium participants to prepare them for active discussions just before the main event of the meeting. Later, the objectives of the Roundtable discussion became broader and included significant educational component for students and symposium participants who were new to the field. Within the last 5 years, the discussion has become a very good platform to exchange opinions and determine global trends and challenges in the field of laser damage in optical materials.

This year's discussion was the fifth event in this line. Topics of the Roundtable discussions are listed below:

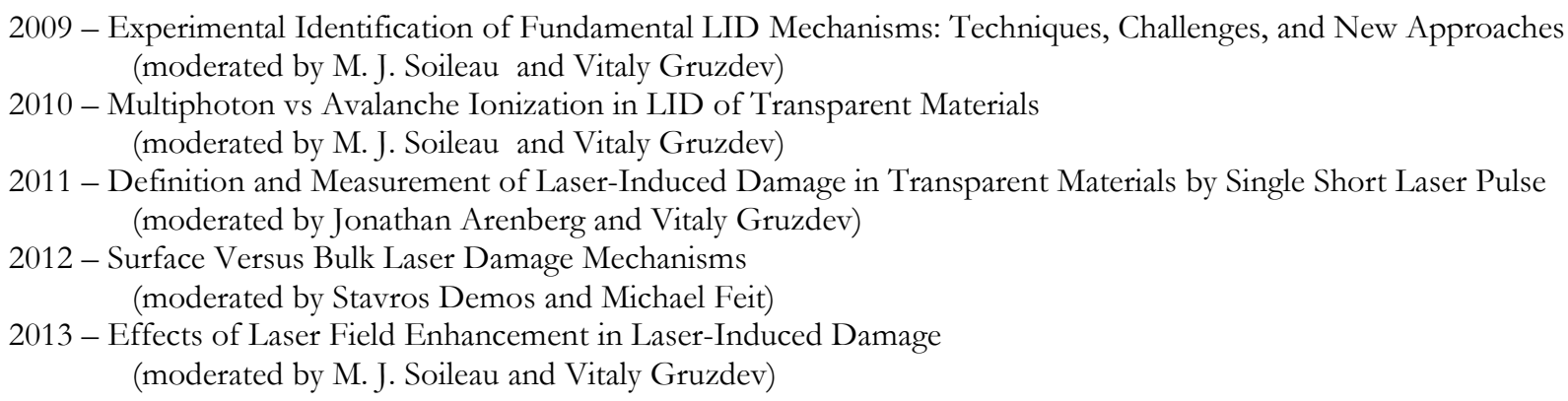

This year, the Roundtable discussion was moderated by Dr. M. J. Soileau (the University of Central Florida, USA) and Dr. Vitaly Gruzdev (University of Missouri). A kick-off presentation delivered by the moderators was focused on the well established fact that propagation of laser radiation through materials could result in several fundamental effects of field enhancement. Those effects are capable of inducing local high electrical fields that enforce laser-material interactions and initiate them at locations of the enhancement. Classical examples of the enhancement effects include Fresnel reflection at rear surface of optical windows, interference in multilayer coatings, and local field enhancement at surface scratches. The discussion was focused on the local field enhancement effects with the major objective to study relations between the field enhancements and amount of laser fluence calculated from measured pulse energy divided by laser-spot area. Of special attention was the correct evaluation of laser fluence and local electric field at front and rear surfaces of thin transparent slabs in view of the well-established low damage threshold of the rear surfaces compared to the front surface. The discussion attracted 47 participants at the beginning with some 12 more participants joined it later.

The feedbacks collected by organizers of this event throughout the 5 years of the Roundtable discussions have suggested very strong interest of symposium participants to educational aspects of the discussion. This year's Roundtable discussion closes the line of those events in their traditional format. Responding to those feedbacks the International Program Committee has decided to change the Roundtable discussion into an educational event with strong emphases on overview lectures or short courses focused on topics directly related to the field of laser damage.

The organizers of the Roundtable discussion express their appreciation to all participants of the discussions held from 2009 for their contributions to success of those events. We are looking forward to success of the new line of pre-symposium events that starts from 2014 ! 
Proc. of SPIE Vol. $8885888501-26$

Downloaded From: https://www.spiedigitallibrary.org/conference-proceedings-of-spie on 26 Apr 2023 Terms of Use: https://www.spiedigitallibrary.org/terms-of-use 